\title{
Problem Based Learning to Enhance Students Critical Thinking Skill via Online Tools
}

\author{
Wan Nur Tasnim Wan Hussin ${ }^{1}$, Jamalludin Harun ${ }^{1} \&$ Nurbiha A. Shukor ${ }^{1}$ \\ ${ }^{1}$ School of Education, Faculty of Social Sciences and Humanities, Universiti Teknologi Malaysia, Johor, \\ Malaysia
}

Correspondence: Wan Nur Tasnim Wan Hussin, School of Education, Faculty of Social Science and Humanities, Universiti Teknologi Malaysia, Johor, Malaysia. E-mail: wntasnim2@live.utm.my

Received: November 6, 2018

Accepted: December 1, 2018

Online Published: December 28, 2018

doi:10.5539/ass.v15n1p14

URL: https://doi.org/10.5539/ass.v15n1p14

\begin{abstract}
Critical thinking in $21^{\text {st }}$ century has been recognized as a skill for citizens. Critical thinking is define as the intellectual thinking skills like analyzing, reasoning, problem solving, creative thinking, making judgement and good decision maker. One way to enhance critical thinking skill is by Problem Based Learning (PBL) approach and it is already widely utilized in educational course as problem solving in learning assessment. Meanwhile, an online tool is the effective approach for teaching and learning in worldwide nowadays. Recently, the previous papers more focus on PBL and the outcome of critical thinking, but not the process, tools to support especially in the new era of learning. There is quite a few paper discuss about using online tools in PBL and critical thinking. The purpose of this review is to look into how the online tools were tackled by previous scholars and the latest trends on online tools in PBL to enhance critical thinking skill. The finding is based on past articles from the other researchers before. Hopefully, this study will contribute to the introduction of a new era of understanding the importance of PBL to enhance critical thinking skill via online tools.
\end{abstract}

Keywords: critical thinking, problem based learning, online tools

\section{Introduction}

Problem based learning (PBL) is one of the learning strategies which drew global focus nowadays (Yusof et al., 2012; Panlumlers \& Wannapiroon, 2015). According to Tiwari et al. (2006), PBL is the best teaching strategy to enhance critical thinking skills and it is supported by proof from empirical studies. However, the traditional PBL also has the limitations. Based on Todd (1991), the limitation of PBL includes peers' reactions (Zabit, 2010). Certain students and teachers want to apply PBL in their teaching and learning whereas the rest want to remain to traditional method. The second limitation is to keep the team together (Zabit, 2010). The teachers need to play the role for supporting each student to unite and to make sure every members of the group become active learners participating in discussion session (Todd, 1991). We can say that the traditional PBL has lack of support and lack of interest from teachers and students. They also think PBL strategy have waste their time and energy.

Thus, in order to solve the traditional PBL difficulties, we need support from technology as the students in this era are actively using the technology. Academicians have agreed to utilize the technology as tool for learning (Balakrishnan \& Gan, 2016; Hartley \& Bendixen, 2001). Up to now, students and teachers have used social networking sites, for instance, Facebook, Instagram, Twitter, and blog. Moran et al. (2011) reported Facebook and Youtube are used by faculty members within and outside the classroom for teaching, for example, to upload notes to students (Balakrishnan \& Gan, 2016). Preece and Shneiderman (2009) claimed the use of social technology making students become more active in constructing their own knowledge because they feel free to share their work online. Preece and Shneiderman (2009) also added, learning via social technologies can increase students' motivation resulting improved works' quality and enhance critical thinking (Hamid et al., 2015).

Critical thinking and experience using technology are vital qualities for students to get the good job (Swart, 2017).Students need to prepare themselves with critical thinking skill because this skill is the employers' focus to hire new employee (Rodzalan \& Saat, 2015). Unluckily, a survey by Manpower Group (2012) reported that the employers are not satisfied with graduates' capability to solve complexity. If this issue is not tackle in this study, the number of unemployed graduates is increasing in the future (Rodzalan \& Saat, 2015). 
There are quite number of papers that speak about critical thinking skills and PBL (Zabit, 2010; Yuan et al, 2008; Awang \& Ramly, 2008). However, there is not much focusing on utilizing online medium to improve students' critical thinking skills by PBL strategy. Hence, this paper discuss about using online tools as medium to increase students' critical thinking skills by PBL strategy.

\subsection{Definition and Concept}

This section discuss about the definition, characteristics and the concept of problem based learning, critical thinking and online tools.

\subsubsection{Problem Based Learning (PBL)}

Based on McMaster model, the concepts of the PBL are uncovering the issue situations, searching information, and discuss and apply new knowledge to the issues (Barrows \& Tamblyn, 1980). From the Barrows (1997) and Zabit (2010) point of view, the PBL's characteristics are learner centred (learners are dependable on their own learning); problem-based (problem used is an ill-structured problem); problem solving (problem used to stimulate the development and reasoning skills); self-coordinate (learners can justify what they study derived from the assignment to solve the problem); reiterative (when learners completed their self study, they will go back to the problems and relate the recent information they obtain from problem solving; collaborative(students will collaborate to solve problem together); self reflecting (learners will make a reflection on their own to latest information, as well as compared with latest problem and generate consideration for the same problem in the forth coming when the problem is answered); self-monitoring (learners will observe, assess the progress and self accomplishment); and lastly is authentic (all necessary PBL's learning behaviour consist of all necessary phases by learners will be evaluated in actual world scenario).

\subsubsection{Critical Thinking}

Critical thinking has 3 skills which are skills to gather and selecting the appropriate information; skill to analyze the data and design hypothesis; and skill to solve the problem (Molitor \& George, 1976). Florea and Hurjui (2015) added that critical thinking is knowledge updating, differentiate differences, identify cause-effect relationships, getting ideas from examples, and evaluate information regarding on truth value, positive or negative effects. Critical thinking must turn out automatically as a student's everyday life until it's become habit as skills (Sinprakob \& Songkram, 2015). Critical thinking needs knowledge and experiences from the learners. Hence, learning by utilizing PBL strategy that chains the experiences offers learners to improve their critical thinking skills (Sinprakob \& Songkram, 2015).

\subsubsection{Online Tool}

According to Centre for Learning and Performance Technologies (2017), online tools can be divided into four categories which are:

1) instructional tools (ex: e-learning authoring tools, quizzing tools and learning management system);

2) content development tools (ex: documentation tools, spreadsheet tools, presentation tools, screen capture tools, audio tools, video and animation tools, photo tools, blogging tools, forms, poling and survey tools, augmented and virtual reality tools);

3) social tools (ex: email, web meeting platforms, messaging and chat, sharing and collaboration tools, discussion forum, and social networks/media) and lastly,

4) personal and professional tools (ex: personal learning/performance systems, search and research tools, social bookmarking tools, mind mapping tools, journaling apps, browsers and extensions and personal devices).

Online courses are now offering by more universities to their students. Based on Pumahapinyo and Suwannatthachote (2014), 2 forms of online courses are fully online courses and hybrid/blended online courses such as Learning Management System (LMS). LMS candisperse, administer, as well as retrieve learning resources. Besides that, LMS can also be a mediator that links relationship between learners, teachers and peers (West, Waddoups, \& Graham, 2007; Rusdi \& Umar, 2015). The examples of the LMS are BlackBoard and Moodle - both supports for collaborative work. In LMS, students who actively participate obtain higher grades compared to individuals who did not use the LMS (Martin-Blas \& Serrano-Fernandez, 2009; Rusdi \& Umar, 2015).

Pumahapinyo and Suwannatthachote (2014), claims that variety tools of technology are utilized to enhance e-learning especially for higher education. Virtual learning environment (VLE) creation is increasing throughout the institution (Phungsuk, Viriyavejakul, \& Ratanaolarn, 2017). To support LMS and VLE, there are several 
online tools available for teaching and learning such as forums, wiki and social media platform. Forums are the tools for developing online discussions and allow participants to interact (reading and discussing) in text-based messages with "anytime and anywhere" (Goggins \& Xing, 2016; Biasutti, 2017). Wikis are for online text collaboration. Students can expand knowledge collaboratively and sharing ideas constantly in Wiki (Biasutti, 2015a; 2015b; $\mathrm{Ng}$, 2016). Moreover, wikis persuade critical thinking through brainstorming in online among students (Balakrishnan \& Gan, 2016).

Online tools like YouTube, is known for online video-sharing tools. YouTube enables users to rank video either "thumbs-up" or "thumbs-down", writing comment, and involve in discussions (Balakrishnan \& Gan, 2016). This shows the use of multimedia elements like videos has been proven effective in learning (Krauskopf et al., 2012; Zahn et al., 2010). Viewers can develop higher-order thinking skills in problem solving and decision making in PBL, by collaborating using You-Tube tool (Balakrishnan \& Gan, 2016).

Many studies have stated positive usage of social media such as Facebook and Twitter for teaching and learning (Manca \& Ranieri, 2016; Tess, 2013). Gao et al. (2012) gave example is micro blogging has a capability to encourage participation, collaborative learning, reflective thinking, and to spread out learning content either within class or outside the class.

\subsection{Objective}

The objective of this paper is to examine how the online tools were tackled by previous scholars to enhance critical thinking skill by using PBL strategy.

\section{Methodology}

The methodology use in this paper is literature review and paper analysis from previous scholars. Electronic database and search engines such as ScienceDirect and Google Scholar were used as a means of searching relevant studies. The keywords used in search finding are "problem based learning", "critical thinking", "online tools", "social media in education", "problem based learning AND critical thinking", "critical thinking AND online tool" and "problem based learning using online tools". Through the keywords, more than 60 articles were found and collected. The range years selected is from 2010 until 2017. First, we read the abstract and evaluated the content for adequacy of our study. Then, we filtered the papers based on the scope. Twenty papers are used as our review including for definition, concepts, characteristics and finding of PBL, critical thinking and online tools as in Table 1 below. Then, only 8 papers are selected for discussion and finding section and were placed in a table sorted according to latest year enclosed in Table 2 in Section 3 (Result and Discussion). The selection of 8 papers is based on the online tools and critical thinking scope.

Table 1. Table of papers selected in general

\begin{tabular}{|c|c|c|}
\hline No. & Author(s) (Year): Title & Section in this paper \\
\hline 1 & $\begin{array}{l}\text { Biasutti (2017): A comparative analysis of forums and wikis as tools for online collaborative } \\
\text { learning. }\end{array}$ & $\begin{array}{l}\text {-Online Tools } \\
\text {-Finding }\end{array}$ \\
\hline 2 & $\begin{array}{l}\text { Swart, R. (2017): Critical thinking instruction and technology enhanced learning from the } \\
\text { student pespective: A mixed methods research study. }\end{array}$ & $\begin{array}{l}\text {-Introduction } \\
\text {-Finding }\end{array}$ \\
\hline 3 & $\begin{array}{l}\text { Phungsuk \& Ratanaolarn (2017): Development of a problem-based learning model via a } \\
\text { virtual learning environment. }\end{array}$ & $\begin{array}{l}\text {-Online Tools } \\
\text {-Finding }\end{array}$ \\
\hline 4 & $\begin{array}{l}\text { Centre for Learning \& Performance Technologies (2017): Directory of Learning \& } \\
\text { Performance Tools. }\end{array}$ & -Online Tools \\
\hline 5 & $\begin{array}{l}\text { Sobaih et al. (2016): To use or not to use? Social media in higher education in developing } \\
\text { countries. }\end{array}$ & $\begin{array}{l}\text {-Introduction } \\
\text {-Finding }\end{array}$ \\
\hline 6 & $\begin{array}{l}\text { Manca \& Ranieri (2016): Facebook and the others. Potentials and obstacles of social media } \\
\text { for teaching in higher education. }\end{array}$ & -Online Tools \\
\hline 7 & Ali et al. (2016): Strengthening the academic usage of social media: An exploratory study. & -Finding \\
\hline 8 & Mansbach (2015): Using Technology to Develop Students' Critical Thinking Skills. & -Finding \\
\hline 9 & $\begin{array}{l}\text { Rusdi \& Umar (2015): Students' Levels Of Critical Thinking, Supportive Behaviors And } \\
\text { Types Of Questions In An Online Forum Learning Environment. }\end{array}$ & $\begin{array}{l}\text {-Online Tools } \\
\text {-Finding }\end{array}$ \\
\hline 10 & $\begin{array}{l}\text { Gan \& Smith (2015): Enhancing students' learning process through interactive digital } \\
\text { media: New opportunities for collaborative learning. }\end{array}$ & $\begin{array}{l}\text {-Introduction } \\
\text {-Online Tools }\end{array}$ \\
\hline
\end{tabular}


11 Hamid et al. (2015): Understanding students' perceptions of the benefits of online social networking use for teaching and learning.

12

Rodzalan \& Saat (2015): The Perception of Critical Thinking and Problem Solving Skill among Malaysian Undergraduate Students.

Sinprakob \& Songkram (2015): A proposed model of problem-based learning on social media in cooperation with searching technique to enhance critical thinking of undergraduate students.

14

Florea \& Hurjui (2015): Critical thinking in elementary school children.

Panlumlers \& Wannapiroon (2015): Design of cooperative problem-based learning activities to enhance cooperation skill in online environment.

16 Khoshneshin (2011): Collaborative critical thinking in online environment.

Zabit (2010): Problem-based Learning on students' critical thinking skills in teaching Business Education in Malaysia: A literature review.

18

Pacific Policy Research Center (2010): 21st Century Skills for Students and Teachers.

Richardson \& Ice (2010): Investigating students' level of critical thinking across instructional strategies in online discussions.

Tiwari et al. (2006): A comparison of the effects of problem-based learning and lecturing on the development of students' critical thinking.
-Introduction

-Introduction

$-\mathrm{CT}$

-Finding

-Critical Thinking

(CT)

-Introduction

-Finding

-Introduction

-PBL

$-\mathrm{CT}$

$-\mathrm{PBL}$

-Finding

-Introduction

\section{Results and Discussion}

To understand the technology's role in improving learning, discovery the contribution of online discussion to foster critical thinking is important (Rusdi \& Umar, 2015). Numerous past researchers agree that students can be connected in deeper thinking when uniting direct online collaborative learning and interaction (Dziuban et al., 2011; Snodgrass, 2011; Swart, 2017). This is benefit for classrooms with larger students in discussion as well as reflection to improve critical thinking. Various authors suggest using appropriate questions and contents to create active discussion for students' engagement and enhance critical thinking (Shieh \& Chang, 2013; Swart, 2017). From the papers selected in Table 1, only 8 papers were chosen and placed into Table 2 below based on online tools to enhance critical thinking based on online tools category. PBL strategy can be more effective by using these online tools.

Table 2. Table of online tools to enhance critical thinking

\begin{tabular}{|c|c|c|c|}
\hline No. & Title, Author(s) (Year) & Findings & $\begin{array}{ll}\text { Online } & \text { Tools } \\
\text { Category } & \end{array}$ \\
\hline 1 & $\begin{array}{l}\text { A comparative analysis of forums and } \\
\text { wikis as tools for online collaborative } \\
\text { learning. Biasutti (2017) }\end{array}$ & $\begin{array}{l}\text { Forum: give opinions, and write material. } \\
\text { Wikis: support thinking skills and knowledge } \\
\text { management skills. }\end{array}$ & Social tools \\
\hline 2 & $\begin{array}{l}\text { Critical thinking instruction and } \\
\text { technology enhanced learning from the } \\
\text { student pespective: A mixed methods } \\
\text { research study. Swart (2017) }\end{array}$ & $\begin{array}{l}\text { LMS online forums: teaching and learning, flexible time } \\
\text { and place, written dialogue capacity storage, processing } \\
\text { time learning and sharing of reflection, and counter } \\
\text { in-person shyness - fostering critical thinking } \\
\text { manipulated by quality of questions and instruction. }\end{array}$ & $\begin{array}{l}\text { Instructional } \\
\text { tools }\end{array}$ \\
\hline 3 & $\begin{array}{l}\text { Development of a problem-based } \\
\text { learning model via a virtual learning } \\
\text { environment. Phungsuk, Viriyavejakul } \\
\text { \& Ratanaolarn (2017) }\end{array}$ & $\begin{array}{l}\text { PBL: apply 'inquiry approach' to look for knowledge } \\
\text { and solutions. } \\
\text { Virtual classroom environment: carry out asynchronous } \\
\text { and synchronous learning. Asynchronous learning: } \\
\text { email/discussion boards as communication. } \\
\text { Synchronous learning: Technology has moved to smart } \\
\text { phones-communication more commonplace. }\end{array}$ & $\begin{array}{l}\text { Personal and } \\
\text { professional } \\
\text { tools }\end{array}$ \\
\hline 4 & $\begin{array}{l}\text { To use or not to use? Social media in } \\
\text { higher education in developing } \\
\text { countries. Sobaih et al. (2016) }\end{array}$ & $\begin{array}{l}\text { Social media: encourage students to involve and build } \\
\text { learning via interaction, critical thinking and } \\
\text { collaboration. }\end{array}$ & Social tools \\
\hline
\end{tabular}


$5 \quad$ Using Technology to Develop Students' Critical Thinking Skills. Mansbach (2015)

Students' Levels Of Critical Thinking, Supportive Behaviors And Types Of Questions In An Online Forum Learning Environment. Rusdi \& Umar (2015)

$7 \quad$ A proposed model of problem-based learning on social media in cooperation with searching technique to enhance critical thinking of undergraduate students. Sinprakob \& Songkram (2015)

8 Collaborative critical thinking in online environment. Khoshneshin (2011)
Facilitators may benefit from online tools to form activities that assist students increase critical thinking skills such as:

Content development tool, social tool

i. Reflection activities

ii. Peer review activities

iii. Digital Storytelling Activities

iv. Discussion forums

v. Small group activities

LMS: system that manages learning activity, chains relationship between students, instructor and peers.

Instructional tool

Involvement of discussion via online in fostering critical thinking is required to aware the function of technology in enhancing learning.

Instructional design models for all students to construct knowledge and critical thinking

Instructional tool

Socratic questioning via Web-based Bulletin Board (WBB) to enhances students' CT skills.
Content

development tool

From the Table 2, we can summarize that there are 3 social tools, 3 for instructional tools, 2 content development tools, and 1 personal and professional tools respectively underlying in online tools category as placed in Table 3 below. Both content and social tools are discussed in paper 5 by Mansbach (2015).

Table 3. Table of online tools category and number of paper(s)

\begin{tabular}{cc}
\hline Online Tools Category & No. of Paper(s) \\
\hline Social Tool & 3 \\
Instructional Tool & 3 \\
Content Development Tool & 2 \\
Personal and Professional Tool & 1 \\
\hline
\end{tabular}

Table 3 shows that Social tool and Instructional tool are the most popular among the 4 online tools category as both of them have 3 articles discussed. Social tool is popular as online tools for learning because nowadays most of people around the world have social media account. Social media has attract the interest of researchers in especially as the learning tool in education (Sobaih et al., 2016; Gupta, 2014; Tess, 2013). Many researchers such as Alufi and Fulton (2014) as well as Hamid et al. (2015) have reported the advantages of using social media in education. The advantages of social media usage are valuable of connectedness, conversation, yet enhancing satisfaction of student life, believe and sharing (Hamid et al., 2015); offering self materials (Dyson et al., 2015); improving teaching engagement and student learning; and students' self confidence and emotional support (Sobaih \& Moustafa, 2016).

Other than that, Instructional tool is also popular and has drawn attention by researchers. LMS is an example of instructional platform utilized by the colleges/universities to facilitate the online courses. Common feature of LMS is the online forum for the students to discover new materials and provides ability for them to collaborate (Rusdi \& Umar, 2015; Du, Yu, \& Olinzock, 2011). Online discussion forums can benefits students with flexible time and place; processing time for learning and sharing of reflection; teaching and learning; and deal with shyness of the students in "unseen" online forum (Swart, 2017; Shieh, 2010). The capability of online discussions in promoting critical thinking is persuaded by the quality of questions generated and the facilitation, similar with the use of the classroom response system (Swart, 2017; Thormann et al., 2013; Richardson \& Ice, 2010). 


\subsection{Social Tools}

Liburd and Christensen (2013) stated that social tool like social media usage can persuade students to participate actively and buildin-depth learning via interaction, collaboration and enhance critical thinking. Wiki and forum are also included in social tools. Ioannou, Brown, and Artino (2015) had produced a systematic comparison using wikis for discussion and forum in collaborative problem-based activities. Findings found that forums have growing nature and wikis have concentrating nature. Students are greater collaborative in wiki activities and extra cooperative for discussions (Biasutti, 2017). Regarding effectiveness, the other researchers, Miyazoe and Anderson (2010) make comparison about online writing activities in university course. From the finding, it showed that wiki is the most favorable according to students, followed by forum. Students utilized the forum activities by sharing ideas, and sharing material so that their peers can read the information. The wiki used to be associated with translation, useful, yet enjoyable tool because of virtual collaboration. Wikis were considered as tools to support learning (Biasutti, 2017). Wikis seem in accordance with have a advantageous impact regarding students then help the development over greater system methods such as thinking competencies then potential management skills (Biasutti, 2017).

Mansbach (2015) suggested instructors to use social tools to form activities which assist students expand critical thinking skills. The activities include:

1) Discussion forums: enable students having conversations along their friends, reply questions that need them to show critical thinking skills, and analyze course content. Students can use the discussions feature in Canvas and sharing the opinions together. Instructors can give instructions for citation course readings to support students' opinions and post the questions in the forum.

2) Small group activities: students can communicate, solve the problem, listen to different point of view, and collaborate with each other to analyze the content of the course. Instructors can use tool for creating and commenting on online presentations such as goreact, and asking students to raises questions about a reading, outline a summarizes presentation and instruct students to critic the author's argument strengths and weaknesses.

For future research, we can consider the activities suggested by Mansbach (2015) which are discussion forums and small group activities by using PBL strategy in social online tools.

\subsection{Instructional Tools}

Modern technologies are assimilated with the instructional design models for students to construct their knowledge, meaningful learning and critical thinking (Sinprakob \& Songkram, 2015). In the 21st century framework of learning, also bothered with problem solving skills, critical thinking skills, information and technology skills (Sinprakob \& Songkram, 2015; Jame Bellanca \& Ron Brandit, 2010). Based on Khoshneshin (2011), to cause more questions in both questioner and responder and at the same time engaging students in deeper thinking, he suggest to use the critical thinking questions such as Socratic PBL questioning.

\subsection{Content Development Tools}

To enhance students' critical thinking skills, Yang (2002) recommend to use structured Web-based Bulletin Board (WBB) discussions as content development tool with PBL Socratic questioning. From his research, the good structured of WBBs significantly fostered students' critical thinking skills and attitudes; the teaching of Socratic questioning assisted students in the process of making decisions; and after disclosure of Socratic questioning, students maintained their critical skills without the lecturer's further facilitation. These discoveries imply that by utilising structured WBB discussions with PBL Socratic questioning might become the effective pedagogy to develop students' critical thinking skills (Khoshneshin, 2011).

Other than that, to help students develop critical thinking skills, Mansbach (2015), suggests the online instructors to use content development tools such as:

1) Reflection activities: provide opportunities for students to track their learning and show progress during the semester. Students may also refer to course materials which aided them improve their thinking. They can use Google Doc for reflecting on what they are learning, describing the progress, and citing course materials. They can share the Google Doc with peers, and instructors can comment the students' work.

2) Peer review activities: students may improve communication skills by giving feedback of their friends' work, and enable students to question what they are reading. Students are more honest giving their feedback online as it can protects students' secrecy. They can use the rubric feature in Canvas. The instructor needs to show the rubric along and instructions of the assignments to the students, for students to 
know the criteria for evaluating their peers and what they will be evaluated.

3) Digital Storytelling Activities: students use images, audio, and video in telling digital stories to portray information. By creating digital stories, students are able to reflect, evaluate and analyze the content of the course. Students can use goreact tool for a narrated Powerpoint.

For future research, we can also consider the activities suggested by Mansbach (2015) which are reflection activities, peer review activities and digital storytelling activities by using PBL strategy in content development online tools.

\subsection{Personal and Professional Tools}

Research papers reported that online discussions can support critical thinking (Richardson \& Ice, 2010; Yang, 2002; Gunawardena et al., 1997). In PBL, students use 'inquiry method' to look for solutions. For that reason, a learning process can result from searching a solution or setting a question that is collaboratively selected by a group of students and their instructors. An educational VLE can afford asynchronous and synchronous learning, whereas PBL is utilized as the process to employ the real world problem (Bignell \& Parson, 2010; Phungsuk, Viriyavejakul, \& Ratanaolarn, 2017). Asynchronous learning can be considered as older form of e-learning in 2016, as students using email as the medium of communication. This is due to technology has moved to smartphones, which have made synchronous learning and communication more common place in the world (Phungsuk, Viriyavejakul, \& Ratanaolarn, 2017). Smart phone is considered as personal and professional tools.

\section{Conclusion}

In conclusion, PBL with the aided of online tools is the best teaching strategy to enhance students' critical thinking skills. From the finding, the online tools in general can be divided into instructional tools, content development tools, social tools and personal and professional tools. Social tool and Instructional tool are the most popular among the four online tools in this study. These online tools can foster critical thinking skills among the students. Instructors can use PBL method to stimulate teaching and learning. Future research is needed to study the effectiveness of using online tools to enhance students' critical thinking skills by PBL approach.

\section{Funding}

The authors would like to thank the Universiti Teknologi Malaysia (UTM) and Ministry of Education (MoE) Malaysia for their support in making this project possible. This work was supported by the Research University Grant [Vote No: Q.J130000.2531.16H55] initiated by UTM and MoE.

\section{References}

Al-ufi, A., \& Fulton, C. (2014). Use of social networking tools for informal scholarly communication in humanities and social sciences disciplines. Procedia-Social and Behavioral Sciences, 147, 436-445. https://doi.org/10.1016/j.sbspro.2014.07.135

Awang, H., \& Ramly, I. (2008). Thinking skill approach through problem-based learning: Pedagogy and practice in the engineering classroom. International Journal of Social Sciences, 3(1), 18-23.

Balakrishnan, V., \& Gan, C. L. (2016). Students' learning styles and their effects on the use of social media technology for learning. Telematics and Informatics, 33(3), 808-821. https://doi.org/10.1016/j.tele.2015.12.004

Barrows, H. S. (1997). Problem-based learning is more than just learning based round problems. The Problem Log, 2(2), 4-5, Retrieved December $\quad 12, \quad$ 2008, from http://pbln.imsa.edu/resources/articles/plog_1997-02-2.pdf

Barrows, H. S., \& Tamblyn, R. M. (1980). Problem-based learning: An approach to medical education. New York: Springer Publishing Company, Inc.

Bellanca, J., \& Brandit, R. (2010). 21st century skills: Rethinking how students learn. USA: Solution tree press.

Biasutti, M. (2015a). Creativity in virtual spaces: Communication modes employed during collaborative online music composition. Thinking Skills and Creativity, 17, 117-129. https://doi.org/10.1016/j.tsc.2015.06.002

Biasutti, M. (2015b). Assessing a collaborative online environment for music composition. Educational Technology \& Society, 18(3), 49-63 (ISSN: 1436-4522n online and 1176-3647 print; Impact factor 1.018).

Biasutti, M. (2017). A comparative analysis of forums and wikis as tools for online collaborative learning. Computers \& Education, 111, 158-171. https://doi.org/10.1016/j.compedu.2017.04.006 
Bignell, S., \& Parson, V. (2010). Best practice in virtual worlds teaching: A guide to using problem-based learning in second life. Retrieved from http://previewpsych.org/BPD2.0.pdf

Centre for Learning and Performance Technologies. (2017). Directory of Learning \& Performance Tools. Retrieved from http://c4lpt.co.uk/directory-of-learning-performance-tools/

Du, J., Yu, C., \& Olinzock, A. A. (2011). Enhancing Collaborative Learning: Impact of "Question Prompts" Design for Online Discussion. Delta Pi Epsilon Journal, 53(1), 28-41.

Dyson, B., Vickers, K., Turtle, J., \& Cowan, S. (2015). Evaluating the use of Facebook to increase student engagement and understanding in lecture-based classes. Higher Education, 69, 303-313. https://doi.org/10.1007/s10734-014-9776-3

Dziuban, C. D., Hartman, J. L., Cavanagh, T. B., \& Moskal, P. D. (2011). Blended courses as drivers of institutional transformation. In A. Kitchenham, (Ed.), Blended Learning across Disciplines: Models for Implementation. Information Science Reference, Hershey, 17-37. https://doi.org/10.4018/978-1-60960-479-0.ch002

Florea, N. M., \& Hurjui, E. (2015). Critical thinking in elementary school children. Procedia-Social and Behavioral Sciences, 180, 565-572. https://doi.org/10.1016/j.sbspro.2015.02.161

Gao, F., Luo, T., \& Zhang, K. (2012). Tweeting for learning: a critical analysis of research on micro blogging in education published in 2008-2011. British Journal of Educational Technology, 43(5), 783-801. https://doi.org/10.1111/j.1467-8535.2012.01357.x

Goggins, S., \& Xing, W. (2016). Building models explaining student participation behavior in asynchronous online discussion. Computers \& Education, 94, 241-251. https://doi.org/10.1016/j.compedu.2015.11.002

Gunawardena, C. N., Lowe, C. A., \& Anderson, T. (1997). Analysis of a global online debate and the development of an interaction analysis model for examining social construction of knowledge in computer conferencing. Journal of Educational Computing Research, 17(4), 397-431. https://doi.org/10.2190/7MQV-X9UJ-C7Q3-NRAG

Gupta, A. (2014). Scope and implications of social media in the context of higher education: review of researches. MIER Journal of Education Studies, Trends \& Practices, 4(2), 231-253.

Hamid, S., Waycott, J., Kurnia, S., \& Chang, S. (2015). Understanding students' perceptions of the benefits of online social networking use for teaching and learning. The Internet and Higher Education, 26, 1-9. https://doi.org/10.1016/j.iheduc.2015.02.004

Hartley, K., \& Bendixen, L. D. (2001). Educational research in the Internet age: Examining the role of individual characteristics. Educ. Res. 30(9), 22-26. https://doi.org/10.3102/0013189X030009022

Ioannou, A., Brown, S. W., \& Artino, A. R. (2015). Wikis and forums for collaborative problem-based activity: A systematic comparison of learners' interactions. The Internet and Higher Education, 24, 35-45. https://doi.org/10.1016/j.iheduc.2014.09.001

Khoshneshin, Z. (2011). Collaborative critical thinking in online environment. Procedia-Social and Behavioral Sciences, 30, 1881-1887. https://doi.org/10.1016/j.sbspro.2011.10.366

Krauskopf, K., Zahn, C., \& Hesse, F. W. (2012). Leveraging the affordances of YouTube: the role of pedagogical knowledge and mental models of technology functions for lesson planning with technology. Comput. Educ. 58(4), 1194-1206. https://doi.org/10.1016/j.compedu.2011.12.010

Liburd, J. J., \& Christensen, I. M. F. (2013). Using web 2.0 in higher tourism education. Journal of Hospitality, Leisure, Sport \& Tourism Education, 12(1), 99-108. https://doi.org/10.1016/j.jhlste.2012.09.002

Manca, S., \& Ranieri, M. (2016). Facebook and the others. Potentials and obstacles of social media for teaching in higher education. Computers \& Education, 95, 216-230. https://doi.org/10.1016/j.compedu.2016.01.012

Manpower Group. (2012). 2012 Talent Shortage Survey. Retrieved June 4, 2013, from http://www.manpowergroup.us/campaigns/talent-shortage2012/pdf/2012_Talent_Shortage_Survey_Results _US_FINALFINAL.pdf

Mansbach, J. (2015). Using Technology to Develop Students' Critical Thinking Skills. Retrieved from https://dl.sps.northwestern.edu/blog/2015/09/using-technology-to-develop-students-critical-thinking-skills/

Martin-Blas, T., \& Serrano-Fernandez, A. (2009). The role of new technologies in the learning process: Moodle as a teaching tool in Physics. Computers \& Education, 52, 35-44. 
https://doi.org/10.1016/j.compedu.2008.06.005

Miyazoe, T., \& Anderson, T. (2010). Learning outcomes and students' perceptions of online writing simultaneous implementation of a forum, blog and wiki in a EFL blended learning setting. System, 36(2), 185-199. https://doi.org/10.1016/j.system.2010.03.006

Molitor, L. L., \& George, K. D. (1976). Development of a Test of Science Process Skills. Journal of Research in Science Teaching, 13, 405-412. https://doi.org/10.1002/tea.3660130504

Moran, M., Seaman, J., \& Tinti-Kane, H. (2011). Teaching, Learning, and Sharing: How Today's Higher Education Faculty Use Social Media. Babson Survey Research Group.

$\mathrm{Ng}$, E. M. (2016). Fostering pre-service teachers' self-regulated learning through self-and peer assessment of wiki projects. Computers \& Education, 98, 180-191. https://doi.org/10.1016/j.compedu.2016.03.015

Panlumlers, K., \& Wannapiroon, P. (2015). Design of cooperative problem-based learning activities to enhance cooperation skill in online environment. Procedia-Social and Behavioral Sciences, 174, 2184-2190. https://doi.org/10.1016/j.sbspro.2015.02.019

Phungsuk, R., Viriyavejakul, C., \& Ratanaolarn, T. (2017). Development of a problem-based learning model via a virtual learning environment. Kasetsart Journal of Social Sciences. https://doi.org/10.1016/j.kjss.2017.01.001

Preece, J., \& Shneiderman, B. (2009). The Reader-to-Leader Framework: Motivating technology-mediated social participation. AIS Transactions on Human-Computer Interaction, 1(1), 13-32. https://doi.org/10.17705/1thci.00005

Pumahapinyo, S., \& Suwannatthachote, S. (2014). Factors affecting the innovation-decision Process to adopt online graduate degree program in Thailand. In The Proceedings of International e-Learning Conference 2014, Bangkok, Thailand.

Richardson, J. C., \& Ice, P. (2010). Investigating students' level of critical thinking across instructional strategies in online discussions. The Internet and Higher Education, 13(1), 52-59. https://doi.org/10.1016/j.iheduc.2009.10.009

Rodzalan, S. A., \& Saat, M. M. (2015). The Perception of Critical Thinking and Problem Solving Skill among Malaysian Undergraduate Students. Procedia-Social and Behavioral Sciences, 172, 725-732. https://doi.org/10.1016/j.sbspro.2015.01.425

Rusdi, S. H., \& Umar, I. N. (2015). Students' Levels of Critical Thinking, Supportive Behaviors and Types Of Questions In An Online Forum Learning Environment. Procedia-Social and Behavioral Sciences, 197, 1752-1758. https://doi.org/10.1016/j.sbspro.2015.07.232

Shieh, R. (2010). A case study of constructivist instructional strategies for adult online learning. Br. J. Educ. Technol., 41(5), 706-720. https://doi.org/10.1111/j.1467-8535.2009.00965.x

Shieh, R. S., \& Chang, W. (2013). Implementing the interactive response system in a high school physics context: intervention and reflections. Australas. J. Educ. Technol., 29(5), 748-761. https://doi.org/10.14742/ajet.331

Sinprakob, S., \& Songkram, N. (2015). A proposed model of problem-based learning on social media in cooperation with searching technique to enhance critical thinking of undergraduate students. Procedia-Social and Behavioral Sciences, 174, 2027-2030. https://doi.org/10.1016/j.sbspro.2015.01.871

Snodgrass, S. (2011). Wiki activities in blended learning for health professional students: enhancing critical thinking and clinical reasoning skills. Australas. J. Educ. Technol., 27(4), 563-580. https://doi.org/10.14742/ajet.938

Sobaih, A. E. E., Moustafa, M. A., Ghandforoush, P., \& Khan, M. (2016). To use or not to use? Social media in higher education in developing countries. Computers in Human Behavior, 58, 296-305. https://doi.org/10.1016/j.chb.2016.01.002

Sobaih, A. E., \& Moustafa, M. (2016). Speaking the same language: the value of social networking sites for hospitality and tourism higher education in Egypt. Journal of Hospitality \& Tourism Education, 28(1), 46-56. https://doi.org/10.1080/10963758.2015.1127169

Swart, R. (2017). Critical thinking instruction and technology enhanced learning from the student perspective: A mixed methods research study. Nurse Education in Practice, 23, 30-39. https://doi.org/10.1016/j.nepr.2017.02.003 
Tess, P. A. (2013). The role of social media in higher education classes (real and virtual) e a literature review. Computers in Human Behavior, 29(5), A60-A68. https://doi.org/10.1016/j.chb.2012.12.032

Thomas, T. (2011). Developing first year students' critical thinking skills. Asian Soc. Sci., 7(4), 26-34. https://doi.org/10.5539/ass.v7n4p26

Thormann, J., Gable, S., Fidalgo, P. S., \& Blakeslee, G. (2013). Interaction, critical thinking, and social network analysis (SNA) in online course. Int. Rev. Res. Open Distance Learn, 14(3), 294-317. https://doi.org/10.19173/irrodl.v14i3.1306

Tiwari, A., Lai, P., So, M., \& Yuen, K. (2006). A comparison of the effects of problem-based learning and lecturing on the development of students' critical thinking. Medical education, 40(6), 547-554. https://doi.org/10.1111/j.1365-2929.2006.02481.x

Todd, S. (1991). Preparing tertiary teachers for problem-based learning. In D. Boud, \& G. Feletti (Eds.), The challenge of problem-based learning (Ch. 13, pp. 131-136.). London: Kogan Page.

West, R. E., Waddoups, G., \& Graham, C. R. (2007). Understanding the experiences of instructors as they adopt a course management system. Educational Technology Research and Development, 55(1), 1-26. https://doi.org/10.1007/s11423-006-9018-1

Yang, Y.-T. C. (2002). Use of structured web-based bulletin board discussions with Socratic questioning to enhance students' critical thinking skills in distance education. Unpublished doctoral dissertation; Purdue University, West Lafayette.

Yuan, H. B., Kunaviktikul, W., Klunklin, A., \& Williams, B. A. (2008). Improvement of nursing students' critical thinking skills through problem-based learning in the People's Republic of China: A quasi-experiment study. Nursing and Health Sciences, 10, 70-76. https://doi.org/10.1111/j.1442-2018.2007.00373.x

Yusof, K. M., Hassan, S. A. H. S., \& Phang, F. A. (2012). Creating a Constructively Aligned Learning Environment using Cooperative Problem Based Learning (CPBL) for a Typical Course. Procedia Social and Behavioral Science, 747-757. https://doi.org/10.1016/j.sbspro.2012.09.712

Zabit, M. N. M. (2010). Problem-based Learning on students' critical thinking skills in teaching Business Education in Malaysia: A literature review. American Journal of Business Education, 3(6), 19. https://doi.org/10.19030/ajbe.v3i6.436

Zahn, C., Pea, R., Hesse, F. W., \& Rosen, J. (2010). Comparing simple and advanced video tools as supports for complex collaborative design processes. J. Learn. Sci., 19(3), 403-440. https://doi.org/10.1080/10508401003708399

\section{Copyrights}

Copyright for this article is retained by the author(s), with first publication rights granted to the journal.

This is an open-access article distributed under the terms and conditions of the Creative Commons Attribution license (http://creativecommons.org/licenses/by/4.0/). 